The Third Walpurgis Night 


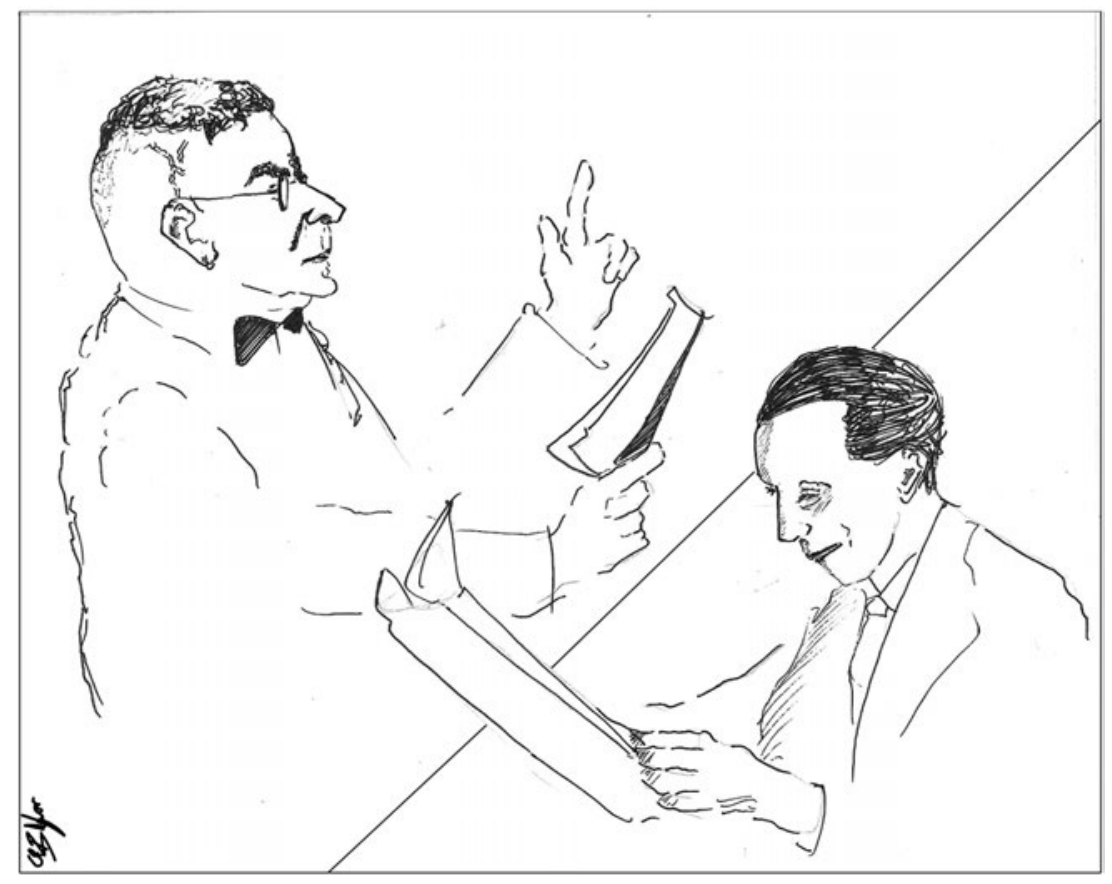

"I am still compared favorably with Goebbels — not a pleasant experience." 
The Third

Walpurgis Night

The Complete Text

KARL KRAUS

TRANSLATED FROM THE GERMAN BY

FRED BRIDGHAM AND EDWARD TIMMS

FOREWORD BY MARJORIE PERLOFF

YALE UNIVERSITY PRESS $\square$ NEW HAVEN \& LONDON

\section{A MARGELLOS}


The Margellos World Republic of Letters is dedicated to making literary works from around the globe available in English through translation. It brings to the English-speaking world the work of leading poets, novelists, essayists, philosophers, and playwrights from Europe, Latin America, Africa, Asia, and the Middle East to stimulate international discourse and creative exchange.

English translation copyright $\odot 2020$ by Fred Bridgham and Edward Timms. Preface copyright (C) 2020 by Yale University. The English translation is based on the 1952 edition of Die Dritte Walpurgisnacht, published in German by Kösel in Munich.

All rights reserved. This book may not be reproduced, in whole or in part, including illustrations, in any form (beyond that copying permitted by Sections 107 and 108 of the U.S. Copyright Law and except by reviewers for the public press), without written permission from the publishers.

Yale University Press books may be purchased in quantity for educational, business, or promotional use. For information, please e-mail sales.press@yale.edu (U.S. office) or sales@yaleup.co.uk (U.K. office).

Set in Electra and Nobel type by Tseng Information Systems, Inc.

Frontispiece: Printed with permission by Otto Bridgham.

Printed in the United States of America.

Library of Congress Control Number: 2019952815

ISBN 978-0-300-23600-2 (hardcover : alk. paper)

A catalogue record for this book is available from the British Library.

This paper meets the requirements of ANSI/NISO Z39.48-1992 (Permanence of Paper).

10987654321 